\title{
Efrapeptin J, a New Down-regulator of the Molecular Chaperone GRP78 from a Marine Tolypocladium sp.
}

\author{
Yoichi Hayakawa, Yuki Hattori, Takashi Kawasaki, Kaneo Kanoh, Kyoko Adachi, \\ Yoshikazu Shizuri, Kazuo Shin-ya
}

Received: March 31, 2008 / Accepted: May 29, 2008

(C) Japan Antibiotics Research Association

\begin{abstract}
A new down-regulator of the molecular chaperone GRP78, efrapeptin J, was isolated from a marine fungus, Tolypocladium sp. AMB18. The molecular formula of efrapeptin $\mathrm{J}$ was established as $\mathrm{C}_{81} \mathrm{H}_{139} \mathrm{~N}_{18} \mathrm{O}_{16}{ }^{+}$by highresolution FAB-MS. The structure was elucidated to be a linear pentadecapeptide containing a hexahydropyrrolo[1,2a]pyrimidinium moiety by NMR and MS analyses. Efrapeptins F, G and J dose-dependently inhibited 2deoxyglucose-induced luciferase expression in HT1080 human fibrosarcoma cells transfected with a luciferase reporter plasmid containing the GRP78 promoter. Efrapeptin $\mathrm{J}$ also inhibited the protein expression of GRP78 in HT1080 cells and MKN-74 human gastric cancer cells. Efrapeptin J induced cell death in HT1080 cells under endoplasmic reticulum stress.
\end{abstract}

Keywords efrapeptin, GRP78, Tolypocladium, transcriptional down-regulator

\section{Introduction}

The endoplasmic reticulum (ER) is a cellular organelle involved in protein synthesis and quality control of protein folding. ER stress induces the expression of several molecular chaperones that prevent unfolded protein accumulation [1]. The molecular chaperone GRP78 can protect cells from ER stress-induced death and is regulated by the promoter ERSE (ER-stress element) [2, 3]. Increased expression of GRP78 causes the resistance of solid tumor cells to low-glucose stress due to poor blood vessel formation [4]. Decreased expression of GRP78 is known to be involved in neuronal cell death in Alzheimer's disease [5]. Thus, down-regulators of GRP78 expression under ER stress are expected to show antitumor activity against solid tumors and up-regulators of GRP78 may prevent ER stress-induced neuronal cell death. In the course of screening for transcriptional regulators of GRP78 using luciferase reporter assay, a marine fungus Tolypocladium sp. AMB18 was found to produce a new GRP78 down-regulator designated efrapeptin J (1, Fig. 1). This paper describes the fermentation, isolation, structure elucidation and biological activity of $\mathbf{1}$.

\section{Results}

\section{Fermentation and Isolation}

The producing organism was cultured in Potato Dextrose Broth (Difco) containing 50\% seawater on a rotary shaker at $25^{\circ} \mathrm{C}$ for 7 days. One-ml portions of the seed culture were inoculated into stainless steel plates $(320 \times 190 \mathrm{~mm})$
Y. Hayakawa (Corresponding author), Y. Hattori, T. Kawasaki: Faculty of Pharmaceutical Sciences, Tokyo University of Science, 2641 Yamazaki, Noda, Chiba 278-8510, Japan, E-mail: hykw@rs.noda.tus.ac.jp

K. Kanoh, K. Adachi, Y. Shizuri: Marine Biotechnology Institute Co. Ltd., 3-75-1 Heita, Kamaishi, Iwate 026-0001, Japan
K. Shin-ya: Biological Information Research Center, National Institute of Advanced Industrial Science and Technology, 2-42 Aomi, Koto-ku, Tokyo 135-0064, Japan 


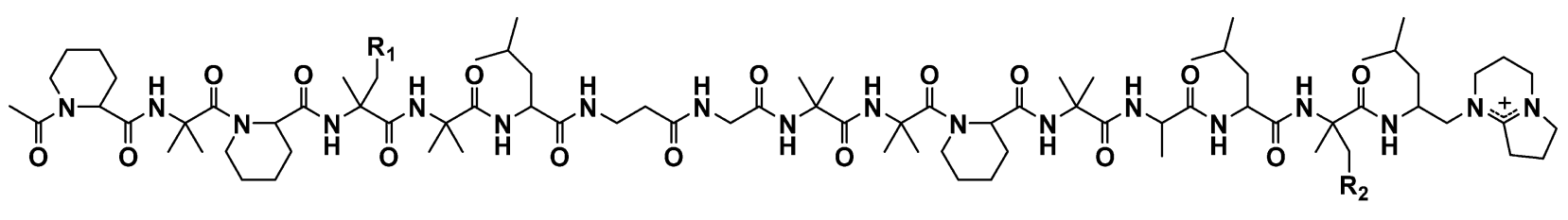

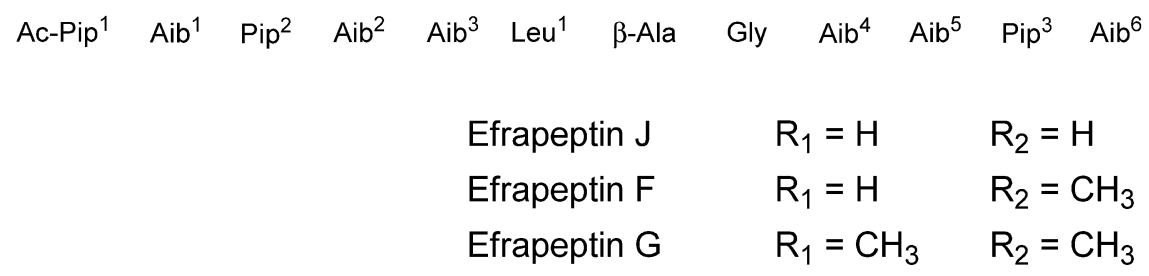

Fig. 1 Structures of efrapeptins J (1), G and F.

containing $400 \mathrm{ml}$ of an agar medium consisting of glucose $0.5 \%$, glycerol $2.0 \%$, yeast extract $0.2 \%$, Pharmamedia (Traders Protein) $2.0 \%$, sodium chloride $0.25 \%$ and agar $1.5 \%$ (pH 6.5 before autoclaving). The fermentation was carried out at $25^{\circ} \mathrm{C}$ for 14 days under static condition.

The whole culture (4.0 liters) was extracted with $\mathrm{Me}_{2} \mathrm{CO}$. After evaporation, the aqueous concentrate was extracted with EtOAc. The extract was applied to a silica gel column, which was washed with $\mathrm{CHCl}_{3}-\mathrm{MeOH}(10: 1)$ and eluted with $\mathrm{CHCl}_{3}-\mathrm{MeOH}(5: 1)$. The active eluate was subjected to HPLC (Senshu Pak PEGASIL ODS $7 \mu, 20$ i.d. $\times$ $250 \mathrm{~mm}$ ). Development of the column with $50 \% \mathrm{CH}_{3} \mathrm{CN}-$ $0.2 \%$ trifluoroacetic acid gave three active fractions, two of which were identified as efrapeptins $F$ and $G$ [6] on the basis of NMR and MS data. The remaining active fraction was concentrated to dryness to yield a colorless powder of $1(50 \mathrm{mg})$.

\section{Structure Elucidation}

The molecular formula of $\mathbf{1}$ was determined to be $\mathrm{C}_{81} \mathrm{H}_{139} \mathrm{~N}_{18} \mathrm{O}_{16}{ }^{+}$(ion) by high-resolution FAB-MS. The IR spectrum showed strong absorption peaks at 3300, 1670 and $1540 \mathrm{~cm}^{-1}$ due to amide groups. The ${ }^{13} \mathrm{C}$-NMR spectrum exhibited 16 amide carbonyl carbons. These data indicated that 1 belongs to the peptide antibiotics. The NMR data are summarized in Table 1 . One-bond ${ }^{1} \mathrm{H}-{ }^{13} \mathrm{C}$ connectivities were established by a heteronuclear multiplequantum coherence (HMQC) [7] experiment.

COSY and heteronuclear multiple-bond correlation (HMBC) [8] experiments revealed the presence of 15 amino acid residues (Fig. 2). A couple of isolated $N$ methylene protons $(\delta 3.73,3.67)$ displayed long-range correlations to a carbonyl carbon $(\delta 171.5)$ to construct a glycine residue (Gly). Four methylene protons including an $N$-methylene group $(\delta 3.74,3.32)$ were coupled to each other and to a carbonyl carbon $(\delta 174.9)$, indicating the presence of a $\beta$-alanine residue ( $\beta$-Ala). An alanine residue
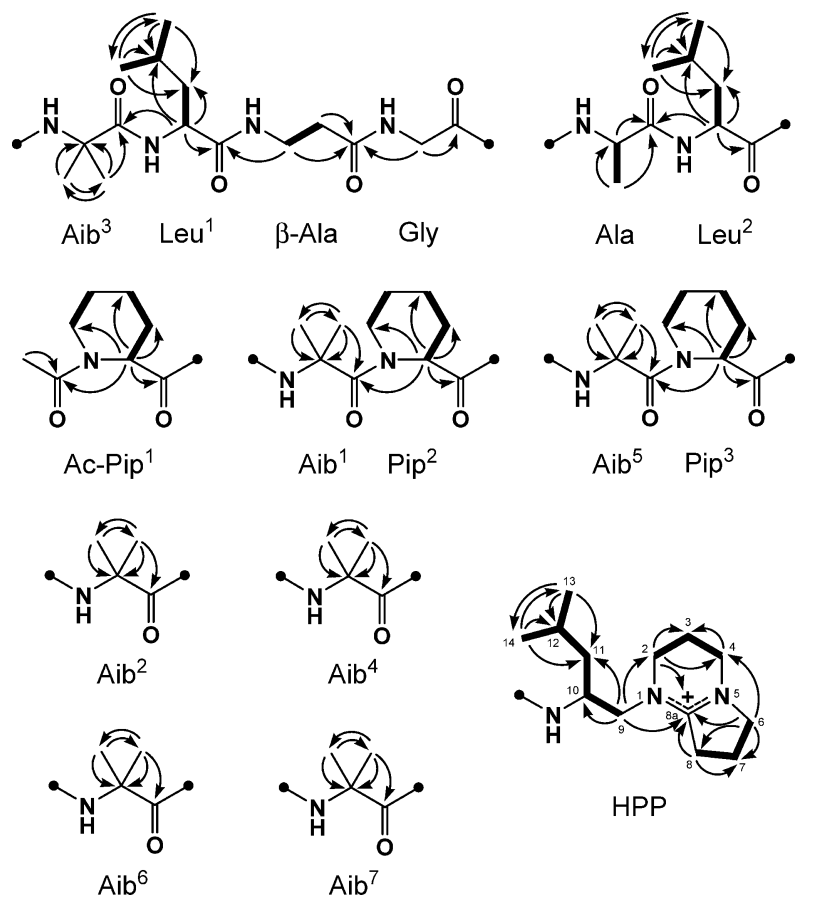

HPP

Fig. 2 Partial structures of efrapeptin J (1).

Bold lines show ${ }^{1} \mathrm{H}-{ }^{1} \mathrm{H}$ spin networks and arrows indicate ${ }^{1} \mathrm{H}$ ${ }^{13} \mathrm{C}$ long-range correlations.

(Ala) was established by ${ }^{1} \mathrm{H}^{13} \mathrm{C}$ long-range correlations to a carbonyl carbon $(\delta$ 177.6) from doublet methyl $(\delta 1.44)$ and $N$-methine $(\delta 4.02)$ protons, which were coupled to each other. Each of three $N$-methine protons $(\delta 5.14,5.03$, 4.95) displayed $\mathrm{CH}-\mathrm{CH}_{2}-\mathrm{CH}_{2}$ spin networks and exhibited long-range correlations to each couple of carbonyl $(\delta$ $173.3,173.6,173.5)$ and $N$-methylene $(\delta 45.8,45.3,44.7)$ carbons. The three $N$-methylene groups were part of three $\mathrm{CH}_{2}-\mathrm{CH}_{2}$ sequences in the COSY spectrum. Comparison of their ${ }^{1} \mathrm{H}$ and ${ }^{13} \mathrm{C}$ chemical shifts with those of pipecolic acid $[9,10]$ identified three pipecolic acid residues (Pip ${ }^{1}$, $\left.\mathrm{Pip}^{2}, \mathrm{Pip}^{3}\right)$. Pip ${ }^{1}$ was required to be $N$-acetylated by ${ }^{1} \mathrm{H}_{-}{ }^{13} \mathrm{C}$ 
Table $1{ }^{13} \mathrm{C}$ - and ${ }^{1} \mathrm{H}-\mathrm{NMR}$ data for efrapeptin $\mathrm{J}(\mathbf{1})$.

\begin{tabular}{|c|c|c|c|c|c|c|c|}
\hline \multicolumn{2}{|l|}{ No. } & \multirow{2}{*}{$\frac{\delta_{\mathrm{C}}}{173.3}$} & \multirow[t]{2}{*}{$\delta_{\mathrm{H}}$} & \multicolumn{2}{|c|}{ No. } & \multirow{2}{*}{$\begin{array}{c}\delta_{\mathrm{C}} \\
175.8\end{array}$} & \multirow[t]{2}{*}{$\delta_{\mathrm{H}}$} \\
\hline Ac-Pip ${ }^{1}$ & 1 & & & $\mathrm{Aib}^{5}$ & 1 & & \\
\hline & 2 & 54.1 & 5.14 & & 2 & 58.4 & \\
\hline & 3 & 27.4 & $2.24,1.65$ & & 3 & 28.0 & 1.52 \\
\hline & 4 & 21.5 & $1.71,1.49$ & & 4 & 25.3 & 1.50 \\
\hline & 5 & 26.0 & $1.73,1.55$ & $\mathrm{Pip}^{3}$ & 1 & 173.5 & \\
\hline & 6 & 45.8 & $3.86,3.23$ & & 2 & 57.0 & 4.95 \\
\hline & $\mathrm{MecO}$ & 173.8 & & & 3 & 26.5 & $2.27,1.60$ \\
\hline & $\mathrm{MeCO}$ & 21.7 & 2.17 & & 4 & 21.2 & $1.67,1.46$ \\
\hline \multirow[t]{4}{*}{$A i b^{1}$} & $\overline{1}$ & 176.2 & & & 5 & 25.8 & $1.66,1.55$ \\
\hline & 2 & 58.1 & & & 6 & 44.7 & $4.24,3.08$ \\
\hline & 3 & 27.6 & 1.46 & $A i b^{6 *}$ & 1 & 177.3 & \\
\hline & 4 & 25.4 & 1.56 & & 2 & 58.3 & \\
\hline \multirow[t]{6}{*}{$\mathrm{Pip}^{2}$} & 1 & 173.6 & & & 3 & 28.3 & 1.49 \\
\hline & 2 & 56.8 & 5.03 & & 4 & 23.9 & 1.50 \\
\hline & 3 & 26.3 & $2.35,1.56$ & Ala & 1 & 177.6 & \\
\hline & 4 & 21.4 & $1.62,1.42$ & & 2 & 53.3 & 4.02 \\
\hline & 5 & 25.8 & $1.71,1.50$ & & 3 & 17.0 & 1.44 \\
\hline & 6 & 45.3 & $4.34,3.04$ & Leu $^{2}$ & 1 & 174.7 & \\
\hline \multirow[t]{4}{*}{$\mathrm{Aib}^{2 *}$} & 1 & 178.2 & & & 2 & 55.7 & 3.93 \\
\hline & 2 & 58.1 & & & 3 & 40.8 & $1.85,1.56$ \\
\hline & 3 & 27.1 & 1.57 & & 4 & 26.1 & 1.79 \\
\hline & 4 & 24.2 & 1.47 & & 5 & 23.5 & 0.94 \\
\hline \multirow[t]{4}{*}{$\mathrm{Aib}^{3}$} & 1 & 177.7 & & & 6 & 21.4 & 0.88 \\
\hline & 2 & 58.0 & & $\mathrm{Aib}^{7 *}$ & 1 & 177.1 & \\
\hline & 3 & 27.9 & 1.40 & & 2 & 58.1 & \\
\hline & 4 & 23.3 & 1.49 & & 3 & 26.7 & 1.47 \\
\hline \multirow[t]{6}{*}{ Leu $^{1}$} & 1 & 175.4 & & & 4 & 25.0 & 1.54 \\
\hline & 2 & 54.3 & 4.19 & HPP & 2 & 45.3 & $3.72,3.35$ \\
\hline & 3 & 40.9 & $1.83,1.67$ & & 3 & 20.0 & $2.11,2.05$ \\
\hline & 4 & 26.3 & 1.69 & & 4 & 43.5 & 3.41 \\
\hline & 5 & 23.9 & 0.96 & & 6 & 55.6 & $3.84,3.73$ \\
\hline & 6 & 21.6 & 0.86 & & 7 & 19.1 & $2.28,2.15$ \\
\hline \multirow[t]{3}{*}{$\beta$-Ala } & 1 & 174.9 & & & 8 & 31.9 & $3.34,2.94$ \\
\hline & 2 & 37.0 & $2.64,2.45$ & & $8 a$ & 166.8 & \\
\hline & 3 & 37.2 & $3.74,3.32$ & & 9 & 57.7 & 3.43 \\
\hline \multirow[t]{2}{*}{ Gly } & 1 & 171.5 & & & 10 & 46.0 & 4.35 \\
\hline & 2 & 45.4 & $3.73,3.67$ & & 11 & 42.0 & $1.61,1.23$ \\
\hline \multirow[t]{4}{*}{$A i b^{4 *}$} & 1 & 177.4 & & & 12 & 25.8 & 1.75 \\
\hline & 2 & 58.1 & & & 13 & 23.7 & 0.92 \\
\hline & 3 & 26.7 & 1.52 & & 14 & 21.5 & 0.88 \\
\hline & 4 & 24.2 & 1.46 & & & & \\
\hline
\end{tabular}

* Interchangeable.

long-range couplings from the $\alpha$-methine of $\mathrm{Pip}^{1}$ and a singlet methyl ( $\delta 2.17)$ to a carbonyl carbon $(\delta 173.8)$. An $N$-methine proton $(\delta 4.19)$ showed long-range correlations to carbonyl ( $\delta$ 175.4), methylene ( $\delta$ 40.9) and methine $(\delta$ $26.3)$ carbons, the latter two of which were coupled to two doublet methyl groups $\left(\delta_{\mathrm{H}} 0.96,0.86\right)$ to form a leucine residue ( $\left.\mathrm{Leu}^{1}\right)$. A similar spin system from an $\mathrm{N}$-methine proton $(\delta 3.95)$ identified another leucine residue $\left(\mathrm{Leu}^{2}\right)$. Seven couples of singlet methyls $\left(\delta_{\mathrm{H}} 1.40 \sim 1.57\right)$ revealed ${ }^{1} \mathrm{H}-{ }^{13} \mathrm{C}$ long-range couplings to the relevant seven quaternary carbons bearing nitrogen $(\delta 58.0 \sim 58.4)$ and seven carbonyl carbons $(\delta$ 176.2, 178.2, 177.4, 177.7, 

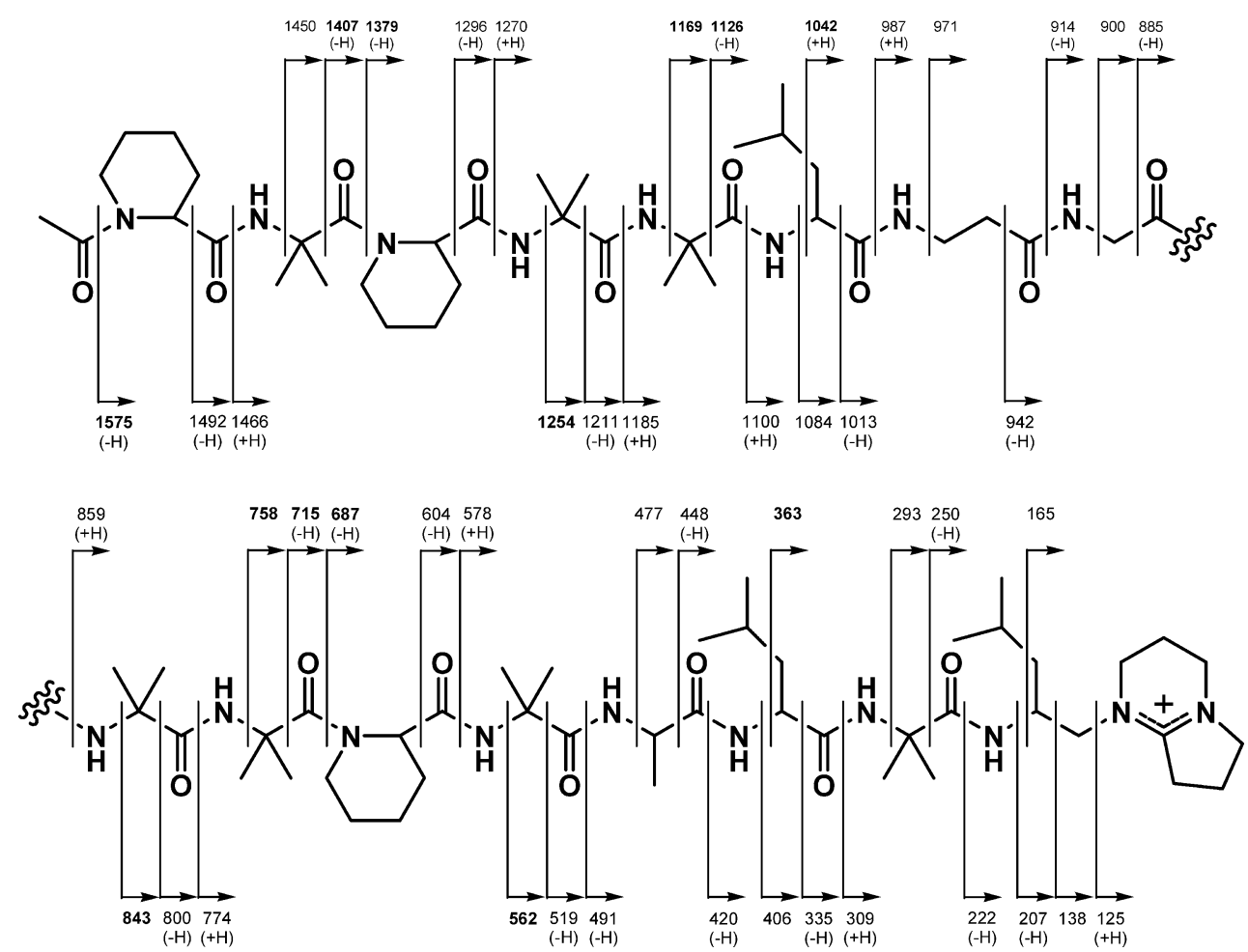

Fig. 3 Mass fragmentation analysis for efrapeptin J (1).

Bold numbers show significant fragment peaks.

$175.8,177.3,177.1)$, respectively. These data indicated the presence of seven $\alpha$-aminoisobutyric acid residues $\left(\mathrm{Aib}^{1} \sim \mathrm{Aib}^{7}\right)$.

In the remaining part, $\mathrm{C}_{13} \mathrm{H}_{25} \mathrm{~N}_{3}{ }^{+}$, the COSY spectrum displayed three spin systems (shown by bold lines in Fig. 2), one of which was expanded to include geminal methyls $(\delta 0.92,0.88)$ attached at $\mathrm{C}-12$ due to long-range couplings from both $13-\mathrm{H}_{3}$ and $14-\mathrm{H}_{3}$ to $\mathrm{C}-11$ and $\mathrm{C}-12$ (Fig. 2). The ${ }^{1} \mathrm{H}$ and ${ }^{13} \mathrm{C}$ chemical shifts required C-2, C-4, C-6, C-9 and $\mathrm{C}-10$ to be bound to nitrogen atoms. Long-range couplings from $9-\mathrm{H}_{2}$ to $\mathrm{C}-2$ and from $6-\mathrm{H}_{2}$ to $\mathrm{C}-4$ indicated the connections via nitrogen atoms between $\mathrm{C}-2$ and $\mathrm{C}-9$ and between $\mathrm{C}-4$ and $\mathrm{C}-6$. The remaining carbon $(\delta$ 166.8) coupled with the four methylenes $\left(2-\mathrm{H}_{2}, 6-\mathrm{H}_{2}, 8-\mathrm{H}_{2}, 9-\mathrm{H}_{2}\right)$ was attributed to an amidinium carbon in a hexahydropyrrolo[1,2-a]pyrimidinium skeleton (HPP), and this assignment completed all the units of $\mathbf{1}$.

In the HMBC spectrum, the $\alpha$-protons of $\mathrm{Pip}^{2}$, Leu ${ }^{1}$, Gly, $\mathrm{Pip}^{3}$ and $\mathrm{Leu}^{2}$ and the $\beta$-methylene protons of $\beta$-Ala revealed long-range correlations to carbonyl carbons in adjacent amino acid residues to establish $\mathrm{Aib}^{1}-\mathrm{Pip}^{2}, \mathrm{Aib}^{3}$ $\mathrm{Leu}^{1}$ - $\beta$-Ala-Gly, $\mathrm{Aib}^{5}-\mathrm{Pip}^{3}$ and Ala-Leu ${ }^{2}$ sequences (Fig. 2).

In the FAB mass spectrum, most fragment peaks included the $C$-terminal amidinium ion according to charge-remote fragmentation [11] (Fig. 3). Distinct fragment peaks with 43 or 83 mass unit differences were assigned to the cleavage at both sides of the quaternary carbon of Aib and both sides of the piperidine ring of Pip. The amino acid sequence was established by assignments of sequential cleavages from the $N$-terminal of $\mathbf{1}$ as shown in Fig. 3. Efrapeptin J (1), a new member of the efrapeptin family, is a linear pentadecapeptide containing a hexahydropyrrolo[1,2-a]pyrimidinium moiety as shown in Fig. 1.

\section{Biological activity}

Luciferase reporter assay was carried out using human fibrosarcoma HT1080 cells transformed with the luciferase gene under the control of the GRP78 promoter (HT1080 GL). Treatment of HT1080 G-L cells with $10 \mathrm{mM}$ of 2deoxyglucose (2DG) for 18 hours increased luciferase activity about 5-fold compared with non-treated control. Efrapeptins J, F and G dose-dependently inhibited the luciferase expression by $2 \mathrm{DG}$ with $\mathrm{IC}_{50} \mathrm{~s}$ of $18,8.5$ and $3.3 \mathrm{nM}$, respectively (Fig. 4). Under the same condition, the efrapeptins did not release lactate dehydrogenase (LDH) from the cells (Fig. 4), indicating that these inhibitory effects were not caused by cytotoxicity. Western blot analysis showed that $\mathbf{1}$ at 30 or $100 \mathrm{nM}$ remarkably reduced 


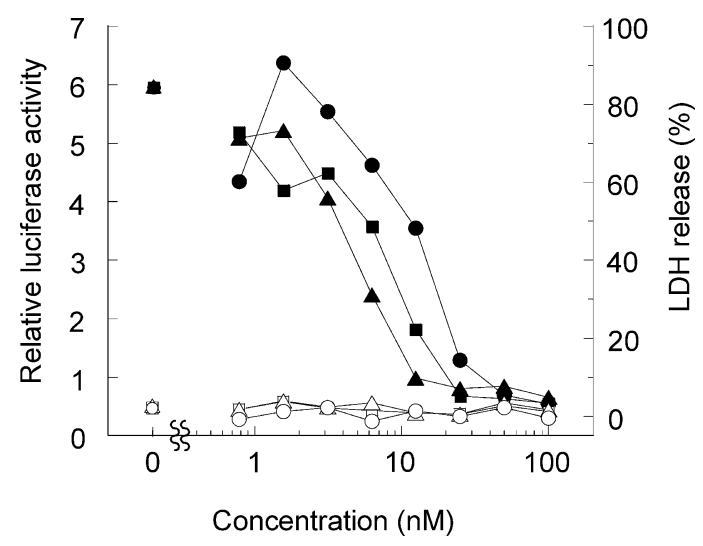

Fig. 4 Effects of efrapeptins on the luciferase expression and LDH release in HT1080 G-L cells.

HT1080 G-L cells were treated with efrapeptin $\mathrm{J}(\mathbf{0}, \mathrm{O}), \mathrm{F}$ $\square)$ or $G(\boldsymbol{\Delta}, \triangle)$ in the presence of 2-deoxyglucose $(10 \mathrm{mM})$ for 18 hours at $37^{\circ} \mathrm{C}$. The relative luciferase activity compared with nontreated control $(\boldsymbol{\bullet}, \mathbf{\square}, \mathbf{\Delta})$ was measured with a luminometer. The $L D H$ release $(O, \square, \triangle$ ) was calculated as free $L D H /$ total $L D H$ using LDH-Cytotoxic Test Wako.

HT1080

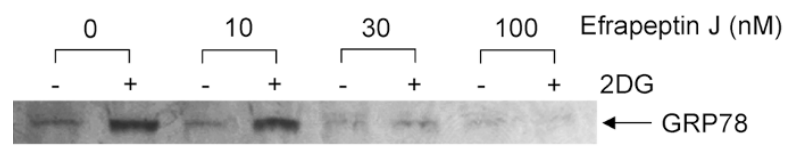

MKN-74

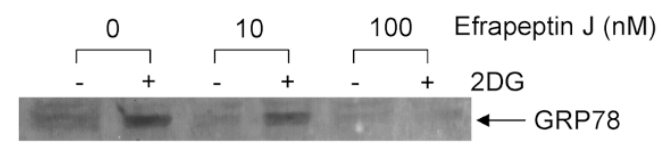

HT1080

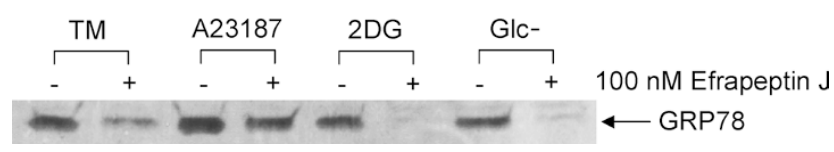

Fig. 5 Western blot analysis of GRP78 expression.

HT1080 cells or MKN-74 cells were treated with efrapeptin J (1) in the presence or absence of an ER-stress inducer for 18 hours. The cell lysate was analyzed by SDS-PAGE followed by Western blotting. TM, A23187 and 2DG indicate $6.25 \mu \mathrm{g} / \mathrm{ml}$ of tunicamycin, $4.0 \mu \mathrm{M}$ of $\mathrm{A} 23187$ and $10 \mathrm{mM}$ of 2-deoxyglucose, respectively.

the expression of GRP78 protein in 2DG-treated HT1080 cells (Fig. 5). Efrapeptin J also inhibited GRP78 expression in MKN74 human gastric cancer cells (Fig. 5). Various ERstress inducers were tested for their effect on the activity of 1. GRP78 induction by tunicamycin or glucose deprivation was inhibited by $\mathbf{1}$, although $\mathbf{1}$ did not affect the induction of GRP78 by the calcium ionophore A23187 (Fig. 5). The effect of 1 on cell viability under ER-stress condition was

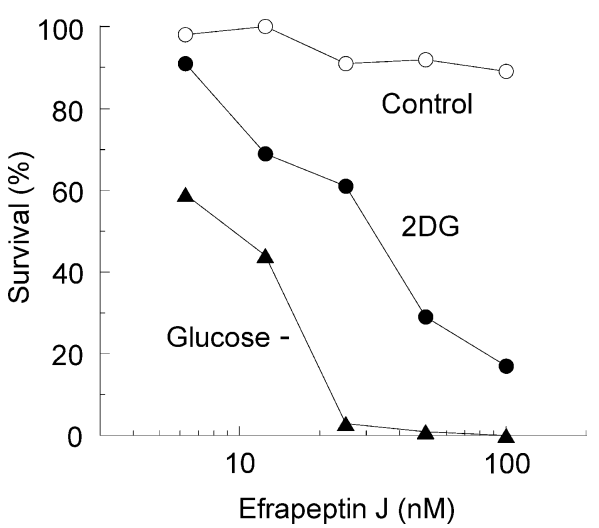

Fig. 6 Selective cytotoxicity of efrapeptin $J(\mathbf{1})$ in the presence of an ER-stress inducer.

HT1080 cells were treated with efrapeptin J for 18 hours in the presence or absence of an ER-stress inducer. The cells were plated and incubated for 7 days to form colonies. The cell viability was calculated as percent of colony number in control culture. 2DG: 2-deoxyglucose (10 mM).

evaluated using colony formation assay. Efrapeptin J induced cell death in HT1080 cells in the presence of 2DG or under a glucose-deprived condition, whereas no cytotoxicity was observed in HT1080 cells treated with only 1 (Fig. 6).

\section{Discussion}

A series of fungal peptides are known as the peptaibols [12], which contain a high proportion of $\alpha, \alpha$-dialkylated amino acids such as Aib and isovaline, an acetylated $N$ terminus and a $C$-terminal amino alcohol. The structure of 1 appears to be related to those of the peptaibols, but is distinguishable due to the presence of a $C$-terminal amidinium. Structurally related pyrrolo[1,2-a]pyrimidines are rarely found in natural products, which include efrapeptins and adenopeptin [9], an apoptosis inducer from Chrysosporium sp.

Efrapeptins have been reported to inhibit mitochondrial $\mathrm{F}_{1} \mathrm{~F}_{\mathrm{O}}$-ATPase [13]. Among down-regulators of GRP78 reported, valinomycin [14] and piericidin A [15] are known as respiratory inhibitors and prunustatin A [16], JBIR-04 and JBIR-05 [17] are derivatives of antimycin A, a respiratory inhibitor targeting complex III. Thus respiratory inhibitors might inhibit transcriptional expression of GRP78 induced by ER stress. Further studies on the biological activities of efrapeptins are in progress. 


\section{Experimental}

\section{Microorganism}

The efrapeptin J producing fungus, AMB18, was isolated from sea mud collected in Aomori prefecture (N $41^{\circ} 02^{\prime} 29.9^{\prime \prime}$, E $\left.140^{\circ} 19^{\prime} 37.6^{\prime \prime}\right)$, Japan, and identified as Tolypocladium sp. from its $28 \mathrm{~S}$ rDNA (D1-D2 region) sequence [18].

\section{Efrapeptin J (1)}

Colorless powder; melting point $132 \sim 137^{\circ} \mathrm{C}$; FAB-MS $(\mathrm{m} / z)$ found: $1620.0610\left(\mathrm{M}^{+}\right)$, calcd. for $\mathrm{C}_{81} \mathrm{H}_{139} \mathrm{~N}_{18} \mathrm{O}_{16}{ }^{+}$: 1620.0616; $[\alpha]_{\mathrm{D}}^{23}+14^{\circ}(c$ 0.24, $\mathrm{MeOH})$; UV $(\mathrm{MeOH})$ end absorption; IR $v_{\max }(\mathrm{KBr}) 3300,2940,1670,1540$, $1440 \mathrm{~cm}^{-1} ;{ }^{13} \mathrm{C}$ - and ${ }^{1} \mathrm{H}-\mathrm{NMR}\left(\mathrm{CD}_{3} \mathrm{OD}\right)$ see Table 1.

\section{Spectroscopic Measurements}

UV and IR spectra were measured on Shimadzu UV-1700 and JASCO FT/IR-410 spectrometers, respectively. Mass spectra were obtained on a JEOL SX-102A spectrometer in the FAB mode using $m$-nitrobenzyl alcohol as matrix and polyethylene glycol as internal standard. NMR spectra were obtained on a JEOL JNM-LA400 spectrometer with ${ }^{1} \mathrm{H}$ NMR at $400 \mathrm{MHz}$ and with ${ }^{13} \mathrm{C}-\mathrm{NMR}$ at $100 \mathrm{MHz}$. Chemical shifts are given in ppm relative to $\mathrm{CHD}_{2} \mathrm{OD}$ at $3.30 \mathrm{ppm}$ for ${ }^{1} \mathrm{H}-\mathrm{NMR}$ and $\mathrm{CD}_{3} \mathrm{OD}$ at $49.0 \mathrm{ppm}$ for ${ }^{13} \mathrm{C}$ NMR.

\section{Cells and Cell Culture}

HT1080 G-L cells were established by transfection of HT1080 human fibrosarcoma cells with the plasmid pGRP70pro160-Luc containing a firefly luciferase gene under the control of the GRP78 promoter [19]. MKN-74 cells were obtained from the Japanese Cancer Research Resources Bank (JCRB). All the cells were maintained in Dulbecco's modified Eagle's medium supplemented with $10 \%$ heat-inactivated fetal calf serum and $0.1 \%$ glucose at $37^{\circ} \mathrm{C}$.

\section{Reporter Assay}

HT1080 G-L cells were plated into 96-well plates at a density of $2 \times 10^{3}$ cells/well. After incubation for 6 hours at $37^{\circ} \mathrm{C}$, the cells were treated with samples in the presence or absence of 2-deoxyglucose $(10 \mathrm{mM})$ for 18 hours at $37^{\circ} \mathrm{C}$. After the medium was removed, $100 \mu$ of Cell Culture Lysis Reagent (Promega) were added to each well. Each $50 \mu$ portion of the cell lysate was transferred into a white 96-well plate. Luciferase activity was measured with an ABI TR717 microplate luminometer (Applied Biosystems) using Luciferse Assay Reagent (Promega).

\section{LDH Release Assay}

HT1080 G-L cells were plated into 96-well plates at a density of $2 \times 10^{3}$ cells/well. After incubation for 6 hours at $37^{\circ} \mathrm{C}$, the cells were cultured with various concentrations of samples for 18 hours at $37^{\circ} \mathrm{C}$. The conditioned medium was transferred into another 96-well plate, and the residual cells were dissolved in $100 \mu \mathrm{l}$ of $0.5 \%$ Triton X-100. LDHCytotoxic Test Wako (Wako Pure Chemical Industries) was used to measure lactate dehydrogenase (LDH) concentrations in the conditioned medium and cell lysate. The rate of free LDH was calculated according to the equation below by using the LDH concentration in the conditioned medium as the amount of free LDH and the LDH concentration in the cell lysate as the amount of intracellular LDH. Rate of free LDH $(\%)=($ amount of free $\mathrm{LDH}) /($ amount of free $\mathrm{LDH}+$ amount of intracellular LDH) $\times 100$.

\section{Western Blotting}

HT1080 cells or MLN-74 cells were plated in 9-cm Petri dishes at a density of $2 \times 10^{5}$ cells $/$ dish. After incubation with or without samples under ER stress for 18 hours at $37^{\circ} \mathrm{C}$, the cells were collected using a cell scraper and lysed in a SDS sample buffer consisting of $10 \%$ glycerol, $5 \% 2$ mercaptoethanol, 2\% sodium dodecyl sulfate (SDS) and $62.5 \mathrm{mM}$ Tris- $\mathrm{HCl}$ (pH 6.8). Protein concentrations of the lysates were measured with a Bio-Rad protein assay kit. Aliquots containing $45 \mu \mathrm{g}$ of protein were resolved on $5 \sim 20 \%$ SDS-polyacrylamide gel and transferred by electroblotting to a polyvinylidene difluoride (PVDF) membrane. The membrane was pretreated with a blocking buffer $\left(0.1 \%\right.$ Tween $20,80 \mathrm{mM} \quad \mathrm{Na}_{2} \mathrm{HPO}_{4}, 20 \mathrm{mM}$ $\mathrm{NaH}_{2} \mathrm{PO}_{4}, 100 \mathrm{mM} \mathrm{NaCl}$ ) containing $10 \%$ skim milk for 20 minutes and incubated with $2.0 \mu \mathrm{g} / \mathrm{ml}$ of mouse monoclonal anti-KDEL (Stressgen) in a blocking buffer containing $4.0 \%$ skim milk for 1 hour. The membrane was washed with a blocking buffer containing $4.0 \%$ skim milk and incubated with horseradish peroxidase-conjugated sheep anti-mouse immunoglobulin antibody $(1: 2000)$ (Amersham Pharmacia Biotech). After washing with a blocking buffer, the protein expression of GRP78 was detected with an ECL detection system (Amersham Pharmacia Biotech).

\section{Colony Formation Assay}

HT1080 cells were plated in 9-cm Petri dishes at a density of $2 \times 10^{5}$ cells/dish. The cells were treated with various concentrations of samples in the presence or absence of 2DG $(10 \mathrm{mM})$ or under a glucose-deprived condition for 18 hours. Trypsinized cells were plated at 200 cells/dish and incubated for 7 days to form colonies. After the colonies 
were stained with $0.01 \%$ crystal violet, the cell viability was calculated as percent of colony number in control culture.

Acknowledgments This work was supported in part by the New Energy and Industrial Technology Development Organization of Japan (NEDO) and a Grant-in-Aid for Scientific Research, The Ministry of Education, Science, Sports and Culture, Japan.

\section{References}

1. Harding HP, Zhang Y, Ron D. Protein translation and folding are coupled by an endoplasmic reticulum-resident kinase. Nature 397: 271-274 (1999)

2. Munro S, Pelham HR. An Hsp70-like protein in the ER: identity with the $78 \mathrm{kd}$ glucose-regulated protein and immunoglobulin heavy chain binding protein. Cell 46: 291-300 (1986)

3. Yoshida H, Haze K, Yanagi H, Yura T, Mori K. Identification of the cis-acting endoplasmic reticulum stress response element responsible for transcriptional induction of mammalian glucose-regulated proteins. Involvement of basic leucine zipper transcription factors. J Biol Chem 273: 33741-33749 (1998); Erratum in: J Biol Chem 274: 2592 (1999)

4. Patricia M, Fernandez SO, Tabbara LK, Jacobs FCR, Manning TN, Tsangaris AM, Schwartz KA, Kennedy SRP. Overexpression of the glucose-regulated stress gene GRP78 in malignant but not benign human breast lesions. Breast Cancer Res Treat 59: 15-26 (2000)

5. Imaizumi K, Miyoshi K, Katayama T, Yoneda T, Taniguchi M, Kudo T, Tohyama M. The unfolded protein response and Alzheimer's disease. Biochim Biophys Acta 1536: 85-96 (2001)

6. Gupta S, Krasnoff SB, Roberts DW, Renwick JAA, Brinen LS, Clardy J. Structure of efrapeptins from the fungus Tolypocladium niveum: Peptide inhibitors of mitochondrial ATPase. J Org Chem 57: 2306-2313 (1992)

7. Summers MF, Marzilli LG, Bax A. Complete ${ }^{1} \mathrm{H}$ and ${ }^{13} \mathrm{C}$ assignments of coenzyme $\mathrm{B}_{12}$ through the use of new twodimensional NMR experiments. J Am Chem Soc 108: 4285-4294 (1986)

8. Bax A, Summers MF. ${ }^{1} \mathrm{H}$ and ${ }^{13} \mathrm{C}$ assignments from sensitivity enhanced detection of heteronuclear multiplebond connectivity by multiple quantum NMR. J Am Chem
Soc 108: 2093-2094 (1986)

9. Hayakawa Y, Adachi H, Kim JW, Shin-ya K, Seto H. Adenopeptin, a new apoptosis inducer in transformed cells from Chrysosporium sp. Tetrahedron 54: 15871-15878 (1998)

10. Boot CM, Tenny K, Valeriote FA, Crews P. Highly $N$ methylated linear peptides produced by an atypical spongederived Aceremonium sp. J Nat Prod 69: 83-92 (2006)

11. Cheng C, Gross ML. Applications and mechanisms of charge-remote fragmentation. Mass Spectrom Rev 19: 398-420 (2000)

12. Bruckner H, Przybylski M. Isolation and structural characterization of polypeptide antibiotics of the peptaibol class by high-performance liquid chromatography with field desorption and fast atom bombardment mass spectrometry. J Chromatogr 296: 263-275 (1984)

13. Cross RL, Kohlbrenner WE. The mode of inhibition of oxidative phosphorylation by efrapeptin (A23871). Evidence for an alternating site mechanism for ATP synthesis. J Biol Chem 253: 4865-4873 (1978)

14. Ryoo I-J, Park H-R, Choo S-J, Hwang J-H, Park Y-M, Bae K-H, Shin-ya K, Yoo I-D. Selective cytotoxic activity of valinomycin against HT-29 human colon carcinoma cells via down-regulation of GRP78. Biol Pharm Bull 29: 817-820 (2006)

15. Hwang J-H, Kim J-Y, Cha M-R, Ryoo I-J, Choo S-J, Cho SM, Tsukumo Y, Tomida A, Shin-ya K, Hwang Y-I, Yoo I-D, Park H-R. Etoposide-resistant HT-29 human colon carcinoma cells during glucose deprivation are sensitive to piericidin A, a GRP78 down-regulator. J Cell Physiol 215: 243-250 (2008)

16. Umeda Y, Chijiwa S, Furihata K, Furihata K, Sakuda S, Nagasawa H, Watanabe H, Shin-ya K. Prunustatin A, a novel GRP78 molecular chaperone down-regulator isolated from Streptomyces violaceoniger. J Antibiot 58: 206-209 (2005)

17. Izumikawa M, Ueda J, Chijiwa S, Takagi M, Shin-ya K. Novel GRP78 molecular chaperone expression downregulators JBIR-04 and -05 isolated from Streptomyces violaceoniger. J Antibiot 60: 640-644 (2007)

18. Bugni TS, Ireland CM. Marine-derived fungi: a chemically and biologically diverse group of microorganisms. Nat Prod Rep 21: 143-163 (2004)

19. Park HR, Tomida A, Sato S, Tsukumo Y, Yun J, Yamori T, Hayakawa Y, Tsuruo T, Shin-ya K. Effect on tumor cells of blocking survival response to glucose deprivation. J Natl Cancer Inst 96: 1300-1310 (2004) 